\title{
OPTIMALISASI WAKAF DI INDONESIA
}

\author{
Choirunnisak S.E.I., M.E. \\ Perbankan Syariah STEBIS IGM Palembang \\ Email: Choirunnisak-umar@stebisigm.ac.id
}

\begin{abstract}
This study aims to find out how to optimize waqf in Indonesia specifically to improve the economy in Indonesia. This research is a libraty research which focuses on qualitative data management with data analysis methods using descriptive analysis methods. The results of this study are seven things that must be done, namely: (1). Carry out a thought approach based on the study of the school of fiqh which is mostly used by Indonesian Muslim communities. (2). Provide socialization regarding the importance of empowering waqf more productively for the acceleration of development of Indonesia. (3) giving an overview and simulation of the benefits and benefits to be obtained by managing waqf productively. (4) Encouraging the creation of qualified HR waqf managers. (5). Encourage the habitual creation of alternative and investment climate that is optimal for the utilization of waqf. (6). Synergize with all related parties. (7) Optimizing the role of the Indonesian Waqf Agency.
\end{abstract}

Kata Kunci: Optimalisasi, wakaf, Indonesia.

\section{PENDAHULUAN}

Perwakafan di Indonesia masih jauh tertinggal dibanding Negara- negara yang mayoritas berpenduduk Islam lain seperti Mesir, Aljazair, Arab Saudi, Kuwait dan Turki. Mereka jauh- jauh hari sudah mengelola wakaf ke arah produktif. Bahkan, di Negara yang penduduk muslimnya minor, pengembangan wakaf juga tak kalah produktif. Singapura misalnya, aset wakafnya, jika dikurskan, berjumlah S\$ 250 juta. Untuk mengelolanya, Majelis Ugama
Islam Singapura (MUIS) membuat anak perusahaan bernama Wakaf Real Estate Singapura (WARES) ${ }^{1}$ Di Indonesia masih banyak aset- aset wakaf yang baru dikelola dengan sangat sederhana bahkan menganggur (idle), sehingga kurang memberikan dampak signifikan bagi masyarakat luas. Hal ini sebagaimana disampaikan Juwaini mengutip hasil survei

1 Syafrudin Arif, Wakaf Tunai sebagai Alternatif Mekanisme Redistribusi Keuangan Islam, Jurnal Ekonomi Islam La_Riba, Volume IV, No. 1, Juli 2010, hal. 86- 87 
yang dilakukan Universitas Islam Negeri (UIN) yang menunjukkan bahwa sebagian besar pengelola wakaf (nadzir) belum dapat memproduktifkan aset wakaf. $^{2}$ Wakaf merupakan instrumen penting dalam sistem ekonomi masyarakat Muslim yang sangat diharapkan dapat membantu meningkatkan taraf hidup mereka menjadi lebih baik. Sementara faktanya pola pengelolaan aset wakaf yang seharusnya memberikan manfaat lebih baik, justru menjadi berkurang nilai manfaatnya (terkena efek free rider) karena kesalahan model pengelolaan yang diterapkan. Sebab sumber daya wakaf justru terbebani biaya kelola yang tinggi tanpa diiringi dengan pengelolaan wakaf melalui skema investasi yang produktif. Sebut saja aset wakaf yang dikelola dalam bentuk masjid atau pemakaman, untuk pelaksanaan kegiatan operasionalnya karena tidak dikelola dengan baik, harus kembali membuat Kotak infak bahkan dipinggir- pinggir jalan. Sebab jika tidak, bangunan masjid yang mengalami

\footnotetext{
2 Ahmad Juwaini, dalam presentasi Arah Pengembangan Wakaf di Indonesia, yang disampaikan pada Seminar "Quo Vadis Wakaf di Indonesia", Tabung Wakaf Indonesia, Universitas Al- Azhar Indonesia. Jakarta, 28 Oktober 2009, mengutip hasil penelitian Universitas Islam Negeri (UIN) Syarif Hidayatullah Jakarta, menyampaikan bahwa 74\% pengelola wakaf (nadzir) di Indonesia belum dapat memproduktifkan aset wakaf.
}

penyusutan, atau pemakaman yang harus dirawat akan terbengkalai dan menjadi tidak terurus.

Namun demikian, penelusuran sejarah membuktikan bahwa wakaf sejatinya telah memiliki peran penting dalam mendorong kehidupan yang lebih baik bagi banyak orang. Dengan mengkonversi aset yang sebelumnya bersifat private menjadi aset public, wakaf membuka akses pemenuhan kebutuhan masyarakat miskin untuk meningkatkan taraf hidupnya. Akses ini sangat penting, melihat masih tingginya angka kemiskinan di Indonesia serta besarnya potensi mereduksi hal tersebut melalui optimalisasi wakaf. ${ }^{3}$

Secara domestik, Nasution memprekirakan potensi wakaf uang di Indonesia mengacu pada tingkat penghasilan per bulan dan jumlah Muslim di Indonesia adalah sebesar Rp.3 Triliun per tahun. Di mana apabila 1 juta saja dari masyarakat Muslim yang berwakaf sebesar Rp. 100.000,per bulan. Kemudian dana tersebut diinvestasikan dengan keuntungan $10 \%$ per

\footnotetext{
${ }^{3}$ Berdasarkan standar Bank Dunia sekitar 53,4\% penduduk Indonseia tergolong miskin. Prosentase ini berarti sekitar 114,8 juta jiwa. Angka ini kurang lebih sama dengan jumlah seluruh penduduk Malaysia, Vietnam dan Kamboja. Lihat: Abdul Azis Setiawan, Tantangan Strategis Institusi Wakaf dalam Program Pengentasan Kemiskinan Masyarakat, Jakarta, Jurnal Kordinat, Volume VIII No.1. 2007.
} 
tahun, maka akan diperoleh penambahan dana wakaf sebesar Rp.120 Milyar per tahun atau Rp.10 Milyar per bulan. ${ }^{4}$ Bahkan Mohsin mencatat potensi wakaf di Indonesia tertinggi sebesar \$14 Milyar per tahun. Lebih besar dari negara lain yang ia teliti, seperti Malaysia (\$1,4 Milyar), Mesir (\$6,5 Milyar), dan Pakistan (\$8 Milyar). Dengan sumber daya sedemikian besar, terlalu sayang bila wakaf hanya dikelola secara tradisional, bahkan idle. ${ }^{5}$

Berangkat dari permasalahan di atas penulis tertarik ingin menulis Optimalisasi wakaf di Indonesia. Penelitian ini merupakan penelitian jenis pustaka (libraty research) yang menitik beratkan pada pengelolaan data secara kualitatif dengan metode analisis data menggunakan metode deskriptifanalisis. Penelitian ini bertujuan untuk menggambarkan atau membeberkan apa yang terjadi sekarang, ${ }^{6}$ dan mengeksplorasi

${ }^{4}$ Nasution, Mustafa Edwin E., M.Sc., MAEP., Ph.D., 2005, Wakaf uang dan Sektor Volunteer, Jakarta, Pusat Kajian Timur Tengah dan Islam Universitas Indonesia.

${ }^{5}$ Dr. Magda Ismail Abdel Mohsin, The Institution of Waqf : A Non-Profit Institution to Financing the Needy Sectors, Paper presented to a conference "Research and Development: The Bridge between Ideals and Realities”, IIUM International Conference on Islamic Banking and Finance. April 24, 2007.

6 Arikunto, S, Prosedur Penelitian Suatu Pendekatan Praktek. (Jakarta: Asdi Mahasatya, 2002), Hlm. 9. penomena-penomena yang tidak dapat dikuantifikasikan. $^{7}$ Selain itu, deskriptif penting karena merupakan metode analisis data yang berfungsi untuk menjelaskan suatu pikiran (fakta) sehingga dapat diterima secara rasional .

\section{PEMBAHASAN}

\section{Pengertian Wakaf}

Secara etimologi, kata wakaf berasal dari bahasa arab waqf, kata kerjanya wakafa yaqifu, artinya berdiri, berhenti, ragu-ragu, menahan, atau mencegah. Selanjutnya kata waqf lebih pepuler digunakan untuk makna maukuf, artinya (sesuatu) yang ditahan, yang dihentikan atau yang diragukan. ${ }^{8}$ Abu bakar Jabir Al- Jazairi mengartikan wakaf adalah sebagai penahan harta sehingga harta tersebut tidak bisa diwarisi, atau dijual, atau dihibahkan, dan mendermakan hasilnya kepada penerimaan wakaf. ${ }^{9}$

Kemudian dalam UU RI No.41 Tahun 2004 tentang wakaf, disebutkan bahwa

7 Satori, Djam'an dan Komariah, Aan. Metodologi Penelitian Kualitatif. (Bandung: Alfabeta, 2013), Hlm. 23.

8 Mukhlisin Muzarie, Fiqih Wakaf , (Yogyakarta: Dinamika,2001), Hal 16.

9 Farid Wadjdy, Mursyid, Wakaf \& Kesejahteraan Umat (Filantripi Islam yang Hampir Terlupakan), (Yogyakarta :Pustaka Pelajar, 2007), hal. 30. 
wakaf adalah perbuatan hukum wakif untuk memisahkan dan atau menyerahkan sebagian harta benda miliknya untuk jangka waktu tertentu sesuai dengan kepentingan guna keperluaan ibadah dan atau kesejahteraaan umum menurut syariah. Dalam perspektif ekonomi, wakaf dapat didefinisikan sebagai pengalihan dana (atau aset lainnya) dari keperluan konsumsi dan menginvestasikannya kedalam aset produktif yang menghasilkan pendapatan untuk konsumsi masa yang akan datang baik individu maupun kelompok.

\section{Sejarah Wakaf}

Keberadaan wakaf telah ada sejak masa Rasulullah saw, diriwayatkan dari Abdullah bin Umar bin Khattab mendapat sebidang tanah di Khaibar. Lalu Umar bin khattab menghadap Rasulullah saw untuk memintak petunjuk tentang apa yang sepatutnya dilakukan terhadap tanah tersebut. Umar berkata kepada Rasulullah saw," $Y a$ Rasulullah saya mendapatkan sebidang tanah di Khaibar dan saya belum pernah mendapat harta lebih baik dari tanah di khaibar itu. Karena itu saya memohon petunjuk tentang apa yang sepatutnya saya lakukan pada tanah itu”, Rasulullah menjawab,"Jika engkau mau, tahanlah tanahmu itu dan engkau sedekahkan”. Lalu
Umar mensedekahkannya dan mensyaratkan bahwa tanah itu tidak boleh diwariskan. Umar salurkan hasil tanah itu buat orangorang fakir, ahli familinya, membebaskan budak, orang-orang yang berjuang fisabilillah, orang-orang yang kehabisan bekal dalam perjalanan dan tamu. Penguasaan wakaf tunai sendiri, boleh makan dari hasil wakaf tersebut dalam batasbats yang ma'ruf(biasa).Ia jika boleh memberi makanorang lain dari wakaf tersebut dan tidak bertindak sebagai pemilik harta sendiri. Sumber-sumber lain menyebutkan bahwa wakaf umar binkhattab itu adalah wakaf pertama dalam Islam.

Menurut habis riwayat an-Nasa' I dan atTurmudzi dari Usman, bahwa Rasulullah saw pernah datang ke Madinah, sedangkan dimadinah ketika itu tidak ada air tawarkecuali sumur rumah, lalu bersabda"siapakah yang mau membeli sumur rumah lalu ia memasukkan timbanya kedalam sumur itu bersama timba-timba kaum muslimin lainnya yangia akan mendapatkan sesuatu yang lebih baik dari pada sumur itu kelakdi surga." Lalu usman membeli sumur itu dari tulang punggung hartanya. Selanjutnya, sumur tersebut diserahkan kepada penduduk Madinah untuk kepentingan hidup mereka. Namun demikian, Usman tetap memanfaatkan airnya 
untuk kepentingan sehari-hari. Pemberian untuk kepentingan umum sebagaimana dimaksud dalam hadist tersebut adalah wakaf. Di dalam hadist lain diceritakan diceritakan di masa Rasulullah saw hidup, Bani Najjar membangun bersama-sama sebuah masjid dan memberikannya untuk kepentinga umum. ${ }^{10}$

\section{Wakaf Zaman Hindia Belanda}

Pada waktu pemerintahan Hindia Belanda, hukum perwakafan telah berlakudalam masyarakat Indonesia berdasrkan Hukum Islam. Administrasi perwakafan tanah baru mulai sejak tahun 1905 dengan dimulainya pendapaftaran tanah wakaf berdasarkan surat edaran sebagai berikut: ${ }^{11}$

a. Surat Edaran Sekretaris Gubernemen tanggal 31 Januari 1905 (Bijblad 1905,No. 6169), yang mewajibkan kepada para Bupati untuk membuat daftar yang memuat segala keterangan untuk benda banda yang bergerak yang boleh pemiliknya ditarik dari peredaran

\footnotetext{
10 Heri Sudaryono, Bank dan Lembaga Keuangan Syariah Deskripsi dan Ilistrasi, (Yogyakarta: Ekinesia, 2007), Hal 292.

${ }^{11}$ Ibid Hal 293
}

umum, baik dengan nama wakaf atau dengan nama lain.

b. Surat Edaran Sekertaris Gubermemen tanggal 4 April 1931(Bijblad, 1934 No.13390), yang memberikan wewenang kepada Bupati untuk memimpin dan menyelesaikan perkara jika terjadi sengketa mengenai tanah wakaf, atas permintaan para pihak yang bersengketa.

c. Surat edaran sekertaris Gubernur tanggal 27 Mei 1935 (Biljlad No. 13480), berisi tata cara para perwakafan, yaitu perlunya perwakafan perlu diketahui oleh bupati untuk diregistrasi dan diteliti tentang keabsahannya.

\section{Wakaf pada Zaman Kemerdekaan}

Setelah kemerdekaan Republik Indonesia tanggal 17 Agustus 1945 maka dibentuklah Undang-undang Pokok Agraria tanggak 24 September 1960 yang mengandung ketentuan berikut: $^{12}$

a. Berdasarkan pasal 2 aturan Peralihan Undang-undang Dasar 1945 , peraturan-peraturan

${ }^{12}$ Ibid Hal. 293-294 
perwakafan Hindia Belanda dinyatakan tetap berlaku. Pada tahun 1958 telah ditetapkan petunjuk-petunjuk mengenai perwakafan oleh Departemen Agama dengan dikeluarkannya Surat Edaran No. 5/D/1956 tentang prosedur perwakafan tanah pada tanggal 8 Oktober 1956.

b. Berdasarkan surat keputusan Mentri Agraria dan Mentri agama No.19. 19/22/37-7 tahun 1959 dan SK.62/Ka/1959, ditetapkanlah pengesahan perwakafan tanahmilik dialihkan kepada kepala Pengawas Agraria Karesidenan, yang pelaksanaannya diatur dengan Surat Pusat Jawatan Agraria kepada Pusat Jawatan Agama tanggal 13-2-1960 No.23/1/34-11.

c. Didalam Undang-undang No. 5 tahun 1960 (UUPA), pada bagian XI, tertera bahwa untuk keperluan suci dan sosial, (pasal 49 ayat (3) ditentukan perwakafan tanah milik dilindungi dan diurat dengan Peraturan Pemerintah.

d. Pada tanggal 17 Mei 1977 ditetapkan Peraturan Pemerintah No. 2 tahun 1977 tentang perwakafan tanah milik, sebagai pelaksanaan tentang pasal 49 ayat (3) UUPA . PP No. 28 tahun 1977 mengatur tata cara perwakafan tanah milik dalam pengertian hak mikil yang baru, serta tata cara pendaftaran tanah wakaf yang terjadi sebelum Peraturan Pemerintah No.28 tahun 1977 yang jumlahnya sangat besar disbanding dengan perwakafan setelah berlakunya PP. No 28/1977.

Intruksi Presiden No 1 tahun 1992 menetapkan kompilasi Hukum Islam, yaitu himpunan hukum material sebagai dokumentasi yuridis yang menjadi pedoman bagi hakim di lingkungan Badan Peradilan Agama sebagai hukum terapan dalam menyelesaikan perkaraperkara yang diajukan kepadanya.

Pada tahun 1922 telah terdapat wakaf di Indonesia, yaitu di Aceh, Gayo, Tapanuli, Jambi, Palembang, Bengkulu, Minahasa, Gorontalo (Sulawesi), Lombok, Jawa Timur, Jawa Tengah dan Jawa Barat. Nama dan benda yang diwakafkan berbedaberbeda, di Aceh disebut wakeub, di Gayo disebut wokos, di Payakumbuh disebut ibah.

Selain perwakafan yang berasal dari Islam juga terdapat perwakafan yang 
berasaldari hukum adat, seperti di Cebeo (Bantan) terdapat tanah semacam tanah wakaf yang disebut huma serang yang digunakan untuk kepentingan umum dan untuk tempat upacar agama. Di Bali tempat semacam tanah wakaf sebagai upacara keagamaan yang biasanya diatas tanah tersebut didirikan Pura. Di daerah kekuasaan raja Jawa terdapat beberapa desa yang semacam tanah wakaf seperti Desa Perdikan (diberi kemerdekaan dari kekuasaan raja), Desa Pekucen ( orangorang yang membawa kunci sebagai penjaga makam raja), Desa Pesantare (desa tempat pendidikan agama) dan Desa Keputihan (orang-orang sakti sebagai keselamat raja) Desa-desa atau tanah tersebut semula adalah milikraja yang digaduhkan (dipinjamkan) kepada seseorang dan keluarganya sebagai hadiah yang pada akhirnya menhadi wakaf. ${ }^{13}$

\section{Dasar Hukum atau Dalil Wakaf}

Secara umum tidak terdapat ayat AlQuran yang menerangkan konsep wakaf secara jelas. Oleh karena wakaf termasuk infaq fi sabilillah, maka dasar yang digunakan para ulama dalam menerangkan

\footnotetext{
${ }^{13}$ Ibid hal 294
}

konsep wakaf ini didasarkan pada umumnya ayat-ayat Al-Quran tentang infaq $f i$ sabilillah. Diantara ayat-ayat tersebut antara lain:

Q.S. Al - Baqarah ayat 267

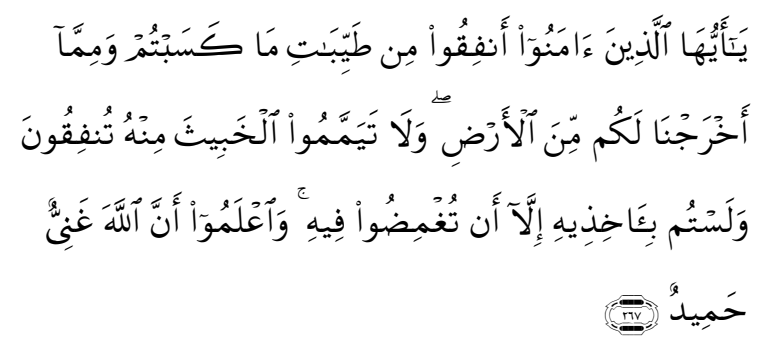

Hai orang-orang yang beriman, nafkahkanlah (di jalan Allah) sebagian dari hasil usahamu yang baik-baik dan sebagian dari apa yang Kami keluarkan dari bumi untuk kamu. dan janganlah kamu memilih yang buruk-buruk lalu kamu menafkahkan daripadanya, Padahal kamu sendiri tidak mau mengambilnya melainkan dengan memincingkan mata terhadapnya. dan ketahuilah, bahwa Allah Maha Kaya lagi Maha Terpuji.

Q.S. Ali- Imran Ayat 92

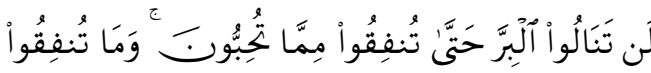

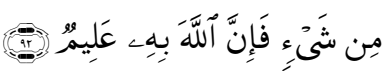
kamu sekali-kali tidak sampai kepada kebajikan (yang sempurna), sebelum kamu menafkahkan sehahagian harta yang kamu cintai. dan apa saja yang kamu nafkahkan Maka Sesungguhnya Allah mengetahuinya.

\section{Rukun dan Syarat Wakaf}


Rukun wakaf ada empat rukun yang mesti dipenuhi dalam wakaf. Pertama, orang berwakaf (al-waqif). Kedua, benda yang diwakafkan (al-mauquf). Ketiga, orang yang menerima manfaat wakaf (al-maufuq 'alaihi). Keempat, lafaz atau ikrar wakaf (sighah). $^{14}$

Adapun syarat-syarat wakaf antara lain:

1. Syarat-syarat orang yang berwakaf (alwaqif). Syarat-syarat al -wakif ada empat; Pertama, orang berwakaf ini mestilah memiliki secara penuh harta itu, artinya dia merdeka untuk mewakafkan harta itu kepada siapa yang dikehendaki. Kedua,dia mestilah orang yang berakal, tidak sah wakaf orang bodoh, orang gila atau orang yang sedang mabuk. Ketiga, dia mestilah baligh. Dan keempat, dia mestilah oaring yang mampu bertindak secara hukum (rasyid). Implikasi orang bodoh, orang yang sedang muflis,dan orang lemah ingatan tidak sah mewakafkan hartanya.

2. Syarat-syarat harta yang diwakafkan (almaufuq). Harta yang diwakafkan itu tidak sah dipindahmilikkan, kecuali apabila ia memenuhi beberapa

14 Andri Soemitra, Bank dan Lembaga Keuangan Syariah, (Jakarta: Kencana Prenada Media Group, 2009), Hal 437-439. persyaratan yang ditentukan oleh; pertama barang yang diwakafkan itu mestilah barang yang berharga. Kedua, harta yang diwakafkan itu mestilah diketahui kadarnya. Jadi apabila harta itu tidak diketahui jumlahnya (majhul), maka pengalihan milik pada ketika itu tidak sah. Ketiga, harta yang diwakafkan itu pasti dimiliki oleh orang yang berwakaf (wakif). Keempat, harta itu mestilah berdiri sendiri, tidak melekat kepada harta lain (mufarrazan) atau disebut juga dengan istilah (ghaira shai').

3. Syarat-syarat orang yang menerima manfaat wakaf (al-mauquf alaih). Dari segi klafikasinya orang yang menerima wakaf ini ada dua macam, yaitu tertentu (mu'ayyan) dan tidak tertentu (ghaira mu'ayyan). Yang dimaksudnya dengan tertentu ialah, jelas orang yang menerima wakaf itu, apakah seorang, dua orang atau satu kumpulan yang semuanya tertentu dan tidak boleh diubah. Sedangkan yang tidak tertentu maksudnya tempat berwakaf itu tidak ditentukan secara terperinci, umpamanya seseorang kafir, miskin, tempat ibadah, dan lain-lain. Persyaratan bagi orangyang menerima wakaf tertentu ini (al- mauquf mu'ayyan) 
bahwa ialah mestilaah orang yang boleh untuk memiliki harta (ahlan li altamlik), maka orang muslim, merdeka dan kafir zimmi yang memenuhi syarat ini boleh memiliki harta wakaf. Adapun orang bodoh, hamba sahaya, dan orang gila tidak sahmenerima wakaf. Syaratsyarat yang berkaitan dengan ghaira mu'ayyan; pertama ialah bahwa yang akan menerima wakaf itu mestilah dapat menjadikan wakaf itu untuk kebaikan yang dengannya mendekatkan diri ke ada Allah. Dan wakaf ini hanya ditujukan untuk kepentingan Islam saja.

4. Syarat-syarat Shigah berkaitan dengan isi ucapan (sighat) perlu ada beberapa syarat. Pertama, ucapan itu mestilah mengandungi kata-kata yang menunjukkan kekalnya (ta'bid). Tidak sah wakaf kalau ucapannya dengan batas tertentu. Kedua, ucapan itu dapat direalisasikan segera (tanjiz), tanpa disangkutkan atau didantungkan kepada syarat tertentu. Ketiga, ucapan itu bersifat pasti. Keempat, ucapan itu tidak diikuti oleh syarat yang membatalkan. Apabila semua persyaratan di atas dapat terpenuhi, maka penguasaan atas tanah wakaf bagi penerima wakaf adalah sah. Pewakaf tidak dapat lagi menarik balik pemilikan harta itu telah berpindah kepada Allah dan penguasaan harta tersebut adalah orangyang menerima wakaf secara umum ia diangap pemiliknya tetap bersifat ghaira tammah. Obyek Wakaf/ Harta yang bisa diwakafkan dan Pemanfaatannya

Harta benda wakaf adalah harta benda yang memiliki daya tahan lama dan/ atau manfaat jangka panjang serta mempunyai nilai ekonomi menurut syariah yang diwakafkan oleh wakif. Harta benda wakaf terdiri dari benda tidak bergerak; dan benda bergerak.

\section{Wakaf Benda Tidak Bergerak}

Pasal 16 ayat 2, UU No. 41 Tahun 2004 dijelaskan bahwa benda tidak bergerak yang dapat diwakafkan, yaitu: ${ }^{15}$

a. Hak atas tanah sesuai dengan ketentuan peraturan perundang-undangan yang berlaku, baik yag sudah maupun yang belum terdaftar.

b. Bangunan atau bagian bangunan yang berdidri di atas tanah.

c. Tanaman dan benda lain yang berdiri di atas tanah.

d. Hak milik atas satuan rumah susun sesuai dengan ketentuan peraturan perundang-undangan yang berlaku.

${ }^{15}$ Ibid 
e. Benda tidak bergerak lain dengan ketentuan syariat dan peraturan perundang-undangan yang berlaku.

Hukum wakaf tanah (terutama hak-hak atas tanah) tidak bisa dilepaskan dari politik hukum pertanahan. Pada dasarnya, tanah dikuasai oleh Negara dan dimanfaatkan sebesar-besarnya untuk kemaslahatan masyarakat. Oleh karena itu, wakaf tanah sebagai institusi keagamaan diharapkan mampu mengisi dan membantu Negara untuk memakmurkan dan/ atau menyejahterakan masyarakat Indonesia.

Tata cara perwakafan tanah milik secara berurutan dapat diuraikan sebagai berikut:

1. Perorangan atau badan hukum yang mewakafkan tanah hak miliknya (sebagai calon wakif) diharuskan datang sendiri di hadapan PPAIW untuk melaksanakan Ikrar Wakaf.

2. Calon wakif sebelum mengikrarkan wakaf, terlebih dahulu menyerahkan kepada PPAIW, surat-surat sebagai berikut:

a. Sertifikat hak milik atau tanda bukti kepemilikan tanah;

b. Surat keterangan kepala desa diperkuat oleh camat setempat mengenai keberatan kepemilikan tanah dan tidak dalam sengketa; c. Surat keterangan pendaftaran tanah; dan

d. Izin bupati/Wali kota madya c.q. Sub direktorat agrarian setempat, hal ini tetutama dalam rangka ata kota atau master plan city.

3. PPAIW mneliti surat-surat dan syaratsyarat, apakah sudah memenuhi untuk pelepasan hak atas tanah (untuk diwakafkan), meneliti saksi-saksi dan mengesahkan susunan nadzir.

4. Di hadapi PPAIW dan dua orang saksi, wakif mengikrarkan atau mengucapkan kehendak wakaf itu kepada nadzir yang telah disahkan.

Ikarar wakaf tersebut diucapkan dengan jelas, tegas, dan dituangkan dalam bentuk tertulis (ikrar wakf bentuk W.1). Sedangkan bagi yang tidak bisa mengucapakan (misalnya bisu), maka dapat menyatakan kehendaknya dengan suatu isyarat dan kemudian mengisi blangko dengan W.1. Apabila wakif itu sendiri tidak dapat menghadap Pejabat pembuat akta Ikrar Wakaf (PPAIW), maka wakif dapat membuat ikrar secara tertulis dengan persetujuan dari Kandepag yang mewilayahi tanah wakaf dan kemudian surat atau naskah tersebut dibacakan dihadapan nadzir setelah mendapat persetujuan dari Kandepag 
dan semua yang hadir dalam upacara ikrar wakaf tersebut ikut menandatangani ikrar wakaf (bentuk W.1).

5. PPAIW segera membuat akta ikrar wakaf (bentuk W.2) rangkap empat dengan dibubuhi materi menurut ketentuan yangberlaku dari selanjutnya, selambat-lambatnya stu bulan dibuat ikrar wakaf, tiap-tiap lembar harus telah dikirim dengan pengaturan perindustriannya sebagai berikut:

a. Akta Ikrar Wakaf :

1) Lembaga pertama disimpan PPAIW;

2) Lembar kedua sebagai lampiran surat pemohonan pendaftaran tanah wakaf ke kantor Subdit Agraria setempat (W.7); dan

3) Lembar ketiga untuk pengadialn Agama setempat.

b. Salinan Akta Ikrar Wakaf:

1) Lembaga pertama untuk wakif;

2) Lembaga kedua untuk nadzir

3) Lembaga ketiga untuk Kandep. Agama kabupataen/kota madya;

4) Lembaga kempat untuk kepala desa setempat.

Disamping telah membuat Akta, PPAIW mencatat dalam Draf akta ikrar wakaf bentuk W.4 dan menyimpannya bersama aktanya dengan baik.

\section{Wakaf benda bergerak}

Benda digolongkan bergerak karena sifatnya yang dapat berpindah atau dipindahkan atau karena ketetapan undangundang. Benda bergerak dapat dihabiskan kecuali air dan bahan bakar minyak yang persediaannya berkelanjutan tidak dapat diwakafkan. Sedangkan benda bergerak yang tidak dapat dihabiskan karena pemakaiandapat diwakafkan. Benda bergerak yang dapat dijadikan sebagai objek wakaf karena sifatnya adalah: ${ }^{16}$

a. Kapal tongkang, perahu, dan kapalkapal feri

b. Pesawatterbang

c. Kendaraan motor

d. Mesin dan peralataan industry yang tidak tertancap padabangunan

e. Logam dan batu mulia

f. Benda lainnya yang tergolong sebagai benda bergrak karena sifatnya memiliki manfaat jangka panjang.

Secara lebih rinci, berdasarkan Pasal 16 ayat 3, UU No.41 tahun 2004 benda bergerak yang dapat diwakafkan, yaitu:

\footnotetext{
${ }^{16} \mathrm{Ibid}$
} 
1. Uang; wakaf uang adalah jenis harta yang diserahkan wakif dalam wakaf uang adalah uang dalam valuta rupiah. Wakaf uang dilakukan oleh Lembaga Keuangan Syariah yang ditunjuk oleh Mentri Agama sebagai LKS Penerimaan Wakaf Uang. Dana wakaf berupa uang dapat diinvestasikan pada set-aset financial dan para asset riil. Investasi pada asset financial dilakukan dipasar modal misalnya berupa saham, obligasi, warran, dan opsi. Sedangkan investasi pada asset riil dapat berbentuk antara lain pembelian aset produktif, pendirian pabrik, pembukuan pertambangan, dan perkebunan.

2. Logam mulia; yaitu logam dan batu mulia yang sifatnyamemiliki manfaat jangka panjang. Objek wakaf berupa logam dan batu mulia agak rumit dimengerti karena dibanyak tempat penyewaan logam dan batu mulia untuk disewakan dengan akad ijarah masih tidak biasa. Oleh karena itu, ada kemungkinan akan menjadi terobosan baru dengan cara menyewakan batu dan logam mulia sehingga pengelolaanya (nazhir) memperbolehkan masukan untuk disalurkan kepada pihak-pihak yang berhak menerima manfaat wakaf.
3. Surat berharga (securities) merupakan instrument pasar modal berupa saham, obligasi, dan sertifikat. Saham dan obligasi diperdagangkan di bursa efek, edangkan sertifikat diperdadangkan di luar bursa melalui bank pemerintah.

4. Kendaraan; yaitu objek wakaf yang dapat dijadikan sebagai pelengkap kegiatan utama atau malah dapat dijadikan kegiatan utama, seperti dijadikan alat angkut yang dikelola secara professional dalam bentuk korporasi atau perusahaan, disewakan atau disewabelikan.

5. Hak atas Kekayaan Intelektual (HaKI); HaKI adalah hak kebendaan yang diakui oleh hukum atas benda yang tidak berwujud berupa kreasi intelektual. Haki mencakup hak cipta, hak paten, hak merek dagang, dan hak desain industri. HaKI dapat dibedakan menjadi dua, pertama hak milik industri yang terdiri dari paten, merek, dan desain produk industry. Kedua, hak ciptayang terdiri dari karya keilmuan, dan karya sastra dan seni. Dalam PP No.42 Tahun 2006 dan 7 macam Haki, yaitu hak cipta, hak merek, hak paten, hak desain industry, hak rahasia dagang, hak sirkuit terpadu, dan hak perlindungan varietas tanaman. MUI telah pula mengakui Haki ini 
dalam fatwa MUI No.1/Munas VII/MUI/5/2005.

6. Hak sewa; merupakan hak yang timbul atas benda bergerak dan benda tidak bergerak atas sewanya. Wakaf bangunan dalam bentuk rumah, rumah susun dan/ atau satuan rumah susun sebagai tempat tinggal/hunian dapat dimanfaatkan secara ekonomis dengan cara disewakan.

7. Benda bergerak lain sesuai dengan ketentuan syariah dan peraturan perundang-undangan yang berlaku seperti mushaf, buku dan kitab.

Sedangkan pemanfaatan harta benda wakaf dijelaskan dalam Pasal 22 UU No. 41 Tahun 2004 dalam rangka mencapai tujuan dan fungsi wakaf, hanya dapat diperuntukkan bagi;

a. Sarana dan kegiatan ibadah

b. Sarana dan kegiatan pendidikan serta kesehatan

c. Bantuan kepada fakir miskin, anak terlantar, yatim piatu, beasiswa

d. Kemajuan dan peningkatan ekonomi umat dan atau

e. Kemajuan kesejahteraan umum lainnya yang tidak bertentangan dengan syariah dan peraturan perundang-undangan.

Pengelolaan dan pengembangan harta benda wakaf dilakukan secara produktif antara lain dengan cara pengumuman, investasi, penanaman modal, produksi, kemitraan, perdagangan, agrobisnis, pertambangan, perindustrian, pengembangan teknologi, pembangunan gedung, apartemen, rumah susun, pasar swalayan, pertokoan, perkantoran, sarana pendidikan ataupun sarana kesehatan dan usaha-usaha yang tidak bertentangan dengan syariah.

Selanjutnya, dalam pengelolaan dan pengembangan harta benda wakaf uang dilakukan dengan, pertama: benda wakaf uang hanya dapat dilakukan melalui investasi pada produk-produk LKS atau instrument keuangan syariah. Kedua nazri hanya dapat mengelola dan mengembangkan harta benda wakaf uang pada LKS penerimaan wakaf uang (LKS-PWU) dalam jangka waktu tertentu apabila ditentukan jangka waktunya. Ketiga: pengelolaan dan pengembangan harta benda uang yang dilakukan pada bank syariah harus mengikuti program lembaga pinjaman simpanan sesuai dengan peraturan perundang-undangan. Keempat. Pengelolaan dan pengembangan harta benda wakaf uang yang dilakukan dalam bentuk investasi diluar bank harus diasuransikan pada asuransi syariah.

Untuk mengamankan harta benda wakaf dari campur tangan pihak ketiga yang merugikan kepentingan wakaf, perlu 
meningkatkan kemampuan professional nazhir. Tugas itu dijalankan oleh Badan Wakaf Indonesia yang merupakan lembaga indepeden yang melaksanakan pemninaan terhadap nazhir, melakukan pengelolaan dan pengembangan harta benda wakaf berskala nasional dan internasional, memberikan persetujuan atas perubahan peruntukan dan status harta benda wakaf, dan memberikan, pertimbangan kepada pemerintah dalam penyusunan kebijakan di dibidang perwakafan.

\section{Penerapan dan Peraturan Wakaf}

1. Badan Wakaf Indonesia

a. Profil BWI

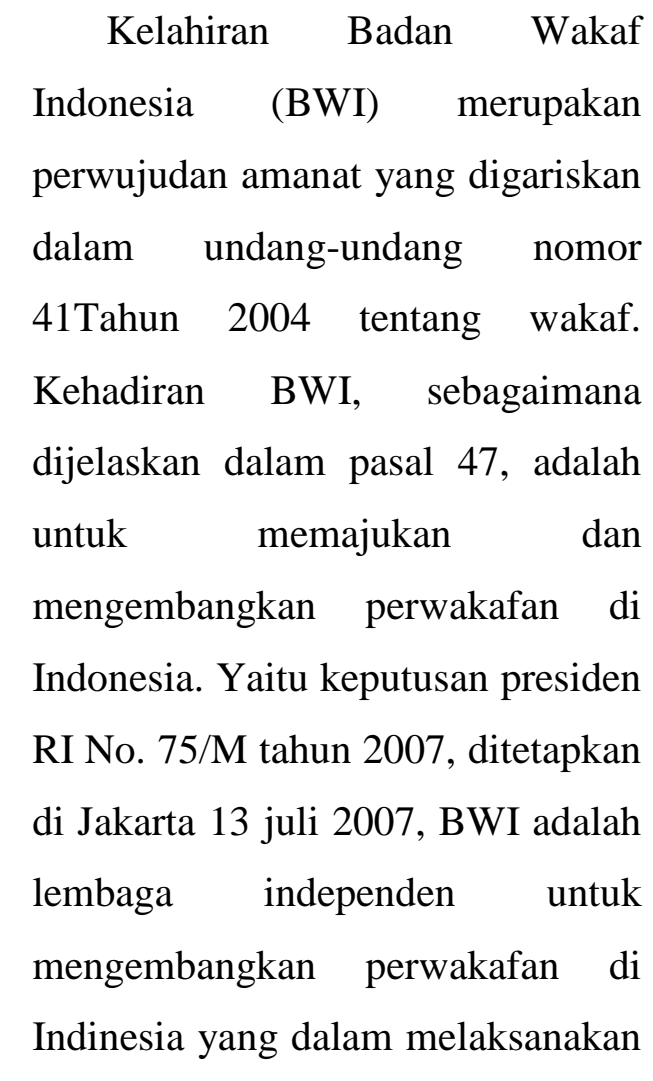

tugasnya bersifat bebas dari pengaruh kekuasaan manapun serta bertanggung jawab kepada masyarakat.

Badan pelaksana merupakan unsur pelaksanaan tugas, sedangkan dewan pertimbangan adalah unsur pengawas pelaksanakan tugas BWI. Jumlah anggota Badan Wakaf Indonesia terdiri paling dikit 20 orang dan paling banyak 30 orang yang berasal dari unsur masyarakat. (Pasal 51-53, UU No.41/2004).

Keanggotaan Badan Wakaf Indonesia diangkat dan diberhentikan oleh presiden. Keanggotaan perwakilan Badan Wakaf Indonesia di daerah diangkat dan diberhentikan oleh Badan Wakaf Indonesia. Keanggotaan Badan Wakaf Indonesia diangkat untuk masa jabatan selama 3 tahun dan dapat diangkat kembali untuk 1 kali jabatan. Untuk pertama kali, pengangkatan anggota Badan Wakaf Indonesia diusulkan kepada presiden melalui mentri. Pengusulan pengangkatan keaanggotaan Badan Wakaf Indonesia kepada presiden untuk selanjutnya dilaksanakan oleh 
Badan Wakaf Indonesia. (Pasal 55,56,57, UU No.41/2004).

b. Tugas dan wewenang

Berdasarkan UU No. 41/2004 Pasal 49 Ayat 1 BWI mempunyai tugas dan wewenang sebagai berikut: ${ }^{17}$

1. Melakukan pembinaan kepada nazhir dalam mengelola dan mengembangkan harta benda wakaf.

2. Melakukan pengelolaan dan pengembangan harta benda wakaf berskala nasional dan internasional.

3. Memberikan persetujuan dan atau izin atas perubahan peruntukan dan status harta benda wakaf.

4. Memberhentikan dan mengganti nazhir.

5. Memberikan persetujuan atas penukaran harta benda wakaf.

6. Memberikan sarana dan pertimbangan kepada pemerintah dalam penyusunan kebijakan di bidang perwakafan.

\section{Wakaf di Zaman Modern}

Pada tahun 1952, pemerintah Mesir telah melarang wakaf pribadi kecuali untuk tujuan derma dan memperbolehkan kredit bank sebagai subjek wakaf. Syiriah pun melarang wakaf keluarga (1949), sedangkan di Libanon tetap diperbolehkan namun hanya dibatasi sampai dua generasi setelah itu kepemilikan kembali pada wakif.

Beberapa alasan mengapa wakaf ahli dihilangkan diantaranya karena sesuai dengan tujuan wakaf, misalnya, menjadikan wakaf ahli sebagai cara untuk menghindari pembagian atau pemecahan harta kakayaan pada ahli waris yang berhak menerimanya setelah wakif meninggal dunia, dijadikan alasan untuk mengelak tuntunan dari krediator atas utang-utanf yang dibuat oleh wakif sebelum mewakafkan tanahnya.

Dalam fikh klasik, menurut Monzer Kahf pembiayaan islam proyek wakaf adalah pembiayaan rekontruksi harta wakaf berbentuk pinjaman, hurk, menambah harta wakaf baru dan penukaran pengganti(subsitusi) harta wakaf, dengan penjelasan sebagai berikut: ${ }^{18}$

1. Pembiayaan wakaf dengan menciptakan harta wakaf baru untuk melengkapi harta wakaf yang lama, seperti perluasan 
Masjid Nabawi di Madinah yang diperluas selama periode pemerintahan Khalifah Umar bin Khattab, Ustman bin Affan, Bani Umayah dan Bani Abbasiyah. Setiap perluasan mewakili penambahan pada harta wakaf yang lama.

2. Pinjaman untuk pembiayai kebutuhan operasional harta wakaf bertujuan untuk mengembalikan tujuan wakaf semula, seperti pinjaman untuk membelih benih, pupuk, dan pekerjaan pengelola tanah wakaf. Syarat yang harus dipenuhi sebelumnya adalah mendapatkan izin dari hakim pengewas. Sumber pinjaman dapat diperoleh dari perorangan maupun lembaga.

3. Penukaran pengganti (subtitusi) harta wakaf hanya mungkin dilakukan karena kegunaan baru dari harta wakaf yang tidak diketahui sebelumnya, seperti pertukaran bangunan sekolah diwilayah yang jarang penduduk dengan bangunan sekolah di wilayah yang padat penduduk. Apabila subtitusi ini telah dijadikan sebagai pembiayaan, tanah perkotaan yang setengah harganya saja dapat mendirikan satu bangunan di daerah lain, maka substitusi ini dapat meningkatkan pendapatan dan menyediakan dana likuid yang diperlukan untuk kegiatan operasional harta wakaf.

4. Pembiayaan hurk adalah sewa berjangka panjang dan lump sum pembayaran di muka yang besar. Modal ini untuk menghindari penjualan harta wakaf. Nadzir dapat menjual hak seepanjang jangka waktu sewa pada suatu nilai nominal sewa secara periodik. Hak dijual untuk suatu jumlah lump sum yang besar dibayar di muka. Pembeli dari hak sewa berjangka panjang dapat membangun tanah wakaf dengan menggunakan sumbernya sendiri atas risiko sendiri sepanjang ia membayar sewa secara periodik kepada pengelola. Nadzir dapat menggunakan lump sum untuk memenuhi tujuan wakaf seperti memperbaiki masjid.

5. Pembiayaan ijaratain, yaitu sewa dengan dua kali pembayaran, terdiri dari uang muka lump sum yang besar untuk merekontruksi harta wakaf yang bersangkutan, dan berupa sewa tahunan secara periodic selama masa sewa. Kasus disebut al- Mursad, di mana pembayaran di muka lump sum tidak secara hukum dianggap bagian dari sewa tetapi merupakanpembayaran di muka oleh penyewa yang harus diperhitungkan terhadap sewa periodic 
yang disepakati setelah rekonstruksi. Model ini hamper sama dengan hukr, pada ijaratain uang muka hanya boleh digunakan untuk merekonstruksi harta wakaf. Harta wakaf dikontrakkan setelah direkonstruksi sesuia dengan spesifikasi yang ditentukan dalam kontrak.

\section{Wakaf tunai (uang)}

Hukum mewakafkan uang tunai merupakan permasalahan yang diperdebatkan dikalangan ulama fikih. Hal ini disebabkan karena cara yag lazim dipakai oleh masyarakat dalam mengembangkan harta wakaf berkisar pada penyewaan harta wakaf, seperti tanah, gedung, rumah, dan semacamnya. Oleh karena itu, sebagian ulama kurang menerima ketika ada diantara ulama yang berpendapat bahwa hukumnya mewakafkan uang dirham dan dinar adalah boleh.

Majlis ulama Indonesia (MUI) pada tanggal 28 shafar $1423 \mathrm{H}$, bertepatan tanggal 11 Mei 2002 M, Komisi Fatwa MUI pusat mengeluarkan fatwa tentang kebolehan (jawaz) hukum wakaf uang selama disalurkan dan digunakan untuk hal-hal sesuai syar'i dan memasukkan surat berharga kepada pengertian uang.
Pengembangan wakaf dewasa ini telah melahirkan konsep sertifikat wakaf uang yang dipersentasikan pertama kali oleh Prof. Mannan di Third Harvard University Forum on Islamic Finance pada Oktober 1999. Di Bangladesh, konsep spektakuler dalam keuangan publik Islam dikenalkan kepada publik pada bulan Desember 1997 dan SIBL baru menerbitkanya secara formal di tanggal 12 Januari 1998. Ide wakaf uang tersebut dikelola oleh SIBL (Social Investment Bank Ltd) dengan mengembangkan pasar modal social melalui pengembangan instrumeninstrumen keuangan Islam seperti, Waqf properties development bond, cash waqf deposit certificate, dan puluhan lembaga bisnis lainnya.

Dengan mengikuti program ini, seorang muslim tidak hanya mengembangkan pasar modal social tetapi juga di bidang investasi social parlemen. Bank dapat menginvestasikan deposit wakaf uang dalam bentuk investasi jangka pendek; kredit mikro dan investasi perusahaan kecil untuk penghapusan kemiskinan dan pemberdayaan keluarga, investasi jangka menengah seperti, industri kerajinan, tenun, garmen, dan sebagainya, serta investasi jangka panjang melalui berbagai industri berat.

Adapun pedoman administrasi operasional wakaf uang yang dipastikan 
SIBL diantaranya, bank akan mengelola dana wakaf dengan nama rekening yang diberikan wakif. Wakaf tunai ini harus diterima wakif dalam bentuk endowment receipt voucher tertentu dan satu sertifikat untuk seluruh nilai harus diterbitkan ketika wakaf tersebut diberikan. Setelah dikelola, dana wakaf akan tetap dan benefit-nya dibagikan kepada maukuf alaihi yang telah ditentukan. Wakif diberikan kebebasan untuk memilih sasaran wakaf, baik sasaran yang sudah teridentifikasi oleh SIBL, seperti Family Rehabilitation, Education and Culture, Health and Sanitation dan Social Utility Service, atau sasaran lainya yang sesuai syariah. Selain itu wakif dapat memberikan dana sepanjang waktu.

Apabila kita menganalisis konsep dari Monzer Kahf, wakaf memiliki makna upaya mengembangkan aset yang melibatkan proses akumulasi modal dan harta kekayaan yang produktif melalui investasi saat ini kemaslahatan yang akan datang, sehingga pengelolaan wakaf memiliki pengorbanan kesempatan konsumsi di masa sekarang untuk tujuan menyediakan penghasilan dan pelayanan yang lebih baik bagi generasi mendatang, karena tujuan proyek wakaf adalah mengoptimalkan fungsi harta wakaf sebagai prasarana meningkatkan kualitas kehidupan sumber daya insani. Menurut
Monzer Kahf, ada beberapa model pembiayaan yang dapat dilaksanakan institusi wakaf, yaitu: ${ }^{19}$ Pembiayaan Murabahah, pembiayaan Istisna', pembiayaan Ijarah, pembiayaan Mudarabah.

Perbedaan Wakaf dengan Shadaqah/Hibah

\begin{tabular}{|l|l|}
\hline \multicolumn{1}{|c|}{ Wakaf } & \multicolumn{1}{c|}{ Shadaqah/ Hibah } \\
\hline $\begin{array}{l}\text { Menyerahkan } \\
\text { kepemilikan } \\
\text { suatu barang } \\
\text { kepada orang } \\
\text { lain }\end{array}$ & $\begin{array}{l}\text { Menyerahkan } \\
\text { kepemilikan suatu } \\
\text { barang kepada pihak } \\
\text { lain }\end{array}$ \\
\hline $\begin{array}{l}\text { Hak milik atas } \\
\text { barang } \\
\text { dikembalikan } \\
\text { kepada Allah } \\
\text { Swt. }\end{array}$ & $\begin{array}{l}\text { Hak milik atas } \\
\text { barang diberikan } \\
\text { kepada penerima } \\
\text { shadaqah/hibah }\end{array}$ \\
\hline $\begin{array}{l}\text { Objek wakaf } \\
\text { tidak boleh } \\
\text { diberikan atau } \\
\text { dijual kepada } \\
\text { pihak lain }\end{array}$ & $\begin{array}{l}\text { Objek shadaqah } \\
\text { hibah boleh } \\
\text { diberikan atau dijual } \\
\text { kepada pihak lain }\end{array}$ \\
\hline $\begin{array}{l}\text { Manfaat barang } \\
\text { biasanya } \\
\text { dinikmati untuk } \\
\text { kepentingan } \\
\text { social }\end{array}$ & $\begin{array}{l}\text { Manfaat barang } \\
\text { dinikmati oleh } \\
\text { penerima }\end{array}$ \\
\hline shadaqah/hibah \\
\hline
\end{tabular}

$$
{ }^{19} \text { Ibid }
$$




\begin{tabular}{|c|c|}
\hline $\begin{array}{l}\text { Objek wakaf } \\
\text { biasanya kekal } \\
\text { zatnya }\end{array}$ & $\begin{array}{l}\text { Objek } \\
\text { shadaqah/hibah } \\
\text { tidak harus kekal } \\
\text { zatnya }\end{array}$ \\
\hline $\begin{array}{l}\text { Pengelolaan } \\
\text { wakaf diserahkan } \\
\text { kepada } \\
\text { administrasi } \\
\text { yang disebut } \\
\text { nadzir/mutawlli }\end{array}$ & $\begin{array}{l}\text { Pengelolaan objek } \\
\text { shadaqah/hibah } \\
\text { diserahkan kepada si } \\
\text { penerima }\end{array}$ \\
\hline
\end{tabular}

Menurut Ai Nur Bayinah, dalam paper yang berjudul Exporing and Empowering Waqf Iinvesment Toward An Acceleration Of Economic Development In Indonesia, ada 7 hal yang bisa dilakukan untuk optimalisasi wakaf di Indonesia khususnya untuk meningkatkan perekonomian Indonesia:

\section{Melakukan pendekatan pemikiran berdasarkan kajian mazhab fikih yang kebanyakan digunakan oleh masyarakat Muslim Indonesia.}

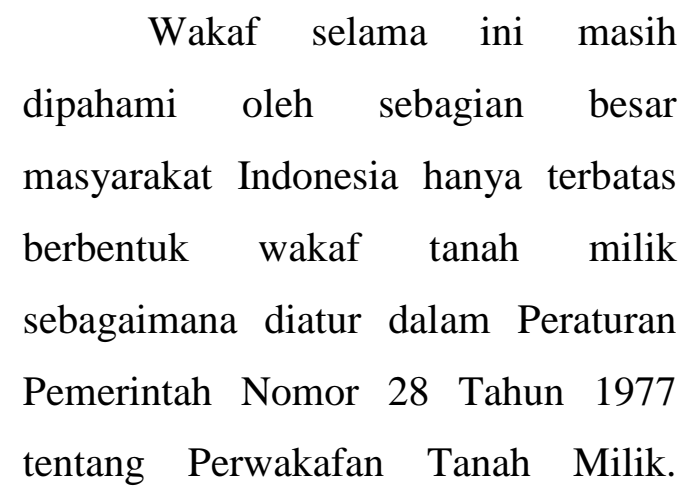

Selama lebih dari 20 tahun. ${ }^{20}$ Hal ini telah membudaya, sehingga ketika dikeluarkannya fatwa Majelis Ulama Indonesia (MUI) tahun 2002 tentang bolehnya berwakaf selain tanah, dalam hal ini berbentuk wakaf uang, transformasi implementasi perwakafan di kalangan masyarakat belum banyak berubah. Peluang mendayagunakan wakaf secara lebih optimal menjadi terbuka lebar ketika pemerintah mengesahkan rancangan Undang- undang Wakaf menjadi Undang- undang Nomor 41 di tahun 2004. Meskipun demikian pengelolaan wakaf secara produktif masih mengundang banyak tanya dan keraguan di kalangan masyarakat mengenai masalah- masalah yang timbul, dan menggerus 'keabadian' wakaf yang biasa dipersyaratkan. Seperti bagaimana bila aset wakaf tidak berkembang disebabkan karena menumpuknya dana (idle fund), turunnya nilai uang karena inflasi, dan hilangnya asset wakaf karena salah dalam pengelolaan

20 Fahmi Medias, Wakaf Produktif dalam Perspektif Ekonomi Islam, Jurnal Ekonomi Islam La_Riba, Volume IV, No. 1, Juli 2010, hal.70 


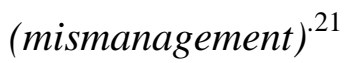

2. Memberikan sosialisasi mengenai pentingnya pemberdayaan wakaf secara lebih produktif bagi percepatan pembangunan di Indonesia.

Mengutip pendapat Imam Malik dengan teorinya al-Mashlahat al-Mursalah, yang berarti melihat pertimbangan kemaslahatan masyarakat atau kepentingan umum, yang juga didukung dengan teori Utility dalam ilmu ekeonomi, yang dipelopori oleh Jeremi Bentham (748-182), bahwa tujuan dari hukum atau perundang- undanganyang dibuat haruslah untuk kemanfaatan yang sebesar- besarnya bagimasyarakat ${ }^{22}$

\section{Memberikan Gambaran Dan} Simulasi Mengenai Keuntungan Dan Manfaat Yang Akan Diperoleh Dengan Mengelola Wakaf Secara Produktif.

Hal ini sejalan dengan penelitian yang juga telah dilakukan oleh Dr.

21 Rozalinda, Manajemen Risiko Investasi Wakaf Uang, Jurnal ISLAMICA, Vol. 6 No. 2, Maret 2012, hal. 301.

22 Yasir, Analisis Pembaruan Hukum Perwakafan, Jurnal Aplikasi Manajemen, Volume 7, Nomor 1, Februari 2009, hal.80- 81
Magda Ismail Abdel Mohsin ${ }^{267}$, dalam papernya yang berjudul The Institution of Waqf : A Non-Profit Institution to Financing the Needy Sectors, yang sedikitnya memberikan dua fakta penting. Yaitu mengenai adanya peran luarbiasa yang dijalankan institusi wakaf selama periode awal Islam, dan besarnya peran institusi nirlaba di Negara berkembang saat ini. ${ }^{23}$ Tercatat bahwa potensi penciptaaan wakaf terutama wakaf uang demikian tinggi. Karenanya, beliau mengusulkan agar lembaga- lembaga wakaf terdorong untuk mengumpulkan seluruh wakaf uang dan menginvestasikannya sesuai dengan model investasi Islami. Dimana hasil keuntungannya digunakan untuk membiayai sektor yang membutuhkan.

\section{Mendorong terciptanya SDM} pengelola wakaf yang mumpuni.

$$
\begin{array}{rcr}
\text { Dr. } & \text { Muhammad } & \text { Anas } \\
\text { Zarka }^{24} \text { dan } & \text { Habib } & \text { Ahmed }^{25}
\end{array}
$$

23 Dr. Magda Ismail Abdel Mohsin, The Institution of Waqf : A Non-Profit Institution to Financing the Needy Sectors, Paper presented to a conference "Research and Development: The Bridge between Ideals and Realities", IIUM International Conference on Islamic Banking and Finance. April 24, 2007.

24 Zarka, Muhammad Anas, Dr., Leveraging Philanthropy : Monetary Waqf for Micro Finance, Paper presented to a symposium "Towards an Islamic 
menegaskan pentingnya pengelolaan wakaf secara profesional. Terutama untuk meningkatkan kesejahteraan masyarakat miskin melalui pemberian pembiayaan kepada mereka yang membutuhkan. Beragam pilihan pengelolaan wakaf yang tersedia tersebut, telah menghilangkan alasan menahan aset wakaf dalam bentuk tradisional. Di mana hal ini dapat menciptakan keenggan berwakaf dan menghambat kinerja wakaf seperti timbulnya korupsi dan pengayaan diri sendiri (self-enrichment) sebagaimana yang menjadi image Negara Muslim, serta ketergantungan berlebihan (excessive dependency) pada properti yang di donasikan waqif seperti disampaikan Muhammad Kholid, Raditya Sukmana, dan Kamal Abdul Kareem Hassan $^{26}$ dalam papernya

Micro Finance", Islamic Finance Project. Islamic Legal Studies Program. Harvard Law School. April 14, 2007

${ }^{25}$ Ahmed, Habib, Waqf- Based Microfinance : Realizing The Social Role of Islamic Finance, Paper written for the International Seminar on "Integrating Waqf in The Islamic Financial Sector", Singapore. March 6- 7, 2007. Islamic Research and Träning Institute (IRTI).

26 Kholid, Muhammad,. Raditya Sukmana dan Kamal Abdul Kareem Hassan, 2007, Waqf through Sukuk Al Intifa'a : A Proposed Generic Model, Paper presented to a conference "Research and Development: The Bridge between Ideals and
Waqf through Sukuk Al-Intifa'a : A

Proposed Generic Model.

5. Mendorong Pembiasaan Penciptaan Alternatif Dan Iklim Investasi Yang Optimal Bagi Pendayagunaan Wakaf.

Dalam penelitiannya, Kholid, dkk menekankan bahwa terus menerus bergantung semata pada penerimaan aset wakaf dari waqif, akan menciptakan masalah ketahanan dalam kontribusi wakaf itu sendiri. Oleh karena itu, lembaga wakaf perlu menciptakan proyek- proyek yng profitable untuk membiayai sektorsektor dasar yang dibutuhkan masyarakat banyak. Menurut penelitian Kholid, proyek primer yang menyediakan kebutuhan dasar seperti pendidikan, kesehatan, dan lain- lain tidak dapat terus menerus dibiayai oleh waqif. Karenanya, proyek sekunder yang menguntungkan harus dibentuk untuk menjaga proyek primer tersebut. Manajer dari proyek sekunder ini harus mampu menciptakan proyek yang menghasilkan pendapatan, sebagaimana kemampuannya untuk

Realities". IIUM International Conference on Islamic Banking and Finance, April 24, 2007. 
meningkatkan dana wakaf.

6. Melakukan sinergi dengan seluruh pihak terkait.

Dalam mengelola wakaf secara produktif, banyak pihak akan ikut terlibat dalam mendukung kesuksesannya. Setidaknya ada empat pihak yang terkait pada saat proses produktivitas wakaf digulirkan. Pertama: Masyarakat pemberi wakaf, dalam hal ini untuk mendorong optimalisasi pengumpulan wakaf, maka perlu sinergi dengan para pengusaha Muslim dan calon waqif lainnya. Kedua: Nadzir, hanya nadzir yang profesional yang berhak menerima amanah wakaf secara produktif, dan hal ini harus diciptakan.

Dibentuk pelatihan- pelatihan dan pembiasaannya. Ketiga: Pihak perbankan Syariah sebagai lembaga keuangan penerima wakaf uang. Ia harus bisa meyakninkan masyarakat bahwa dana mereka akan aman dan dikelola dengan sangat baik. Keempat: Peran pemerintah dalam memberikan payung hukum, sekaligus insentif bagi pemberi wakaf, sebab telah membantu mengurangi permasalahan ekonomi bangsa, dalam hal ini khususnya berupa manfaat yang diterima oleh penerima wakaf (mauquf'alaih).

7. Optimalisasi peran Badan Wakaf Indonesia.

Pemerintah telah melakukan tindakan yang sangat signifikan dengan membentuk Badan Wakaf Indonesia (BWI) yang diharapkan dapat berfungsi dengan optimal, sebagaimana badan wakaf yang terbentuk di Mesir misalnya. Sehingga diharapkan badan wakaf ini dapat memberikan daya dukung yang luar biasa bagi terlaksananya program wakaf produktif di Indonesia.

\section{Kesimpulan}

Wakaf di Indonesia harus bisa di optimalkan lagi, hingga saat ini sudah ada kemajuan, namun belum menyentuh sampai ke tingkat kecamatan dan desa-desa guna memberikan pemahaman wakaf dan perkembangan wakaf bagi masyarakat yang lebih baik. Saat ini sosialisasi wakaf belum merata hanya pada tingkat kota, dan dunia kampus.

\section{DAFTAR PUSTAKA}

Djam'an. Satori, dan Komariah, Aan. Metodologi Penelitian Kualitatif. Bandung: Alfabeta, 2013. 
Masyita Dian, Muhammad Tasrif, dan Abdi Suryadinata Telaga. 2002. A Dynamic Model for Cash Waqf Management as One of The Alternatif Instruments for the Poverty Allevation in Indonesia Lihat juga Dian Masyita, Preliminary Implementation Model Design of Cash Waqf Certificatte as Alternative Instrument for Poverty Alleviation in Indonesia using System Dynamics Methodology. Thesis, ITB. Muzarie, Mukhlisin., Fiqih Wakaf, Yogyakarta: Dinamika,2001.

S., Arikunto, Prosedur Penelitian Suatu Pendekatan Praktek. Jakarta: Asdi Mahasatya, 2002.

Soemitra,Andri, Bank dan Lembaga Keuangan Syariah, Jakarta: Kencana Prenada Media Group, 2009.

Sudaryono,Heri, Bank dan Lembaga Keuangan Syariah Deskripsi dan Ilistrasi, Yogyakarta: Ekinesia, 2007. Wadjdt, Farid, Mursyid, Wakaf \& Kesejahteraan Umat (Filantripi Islam yang Hampir Terlupakan), Yogyakarta :Pustaka Pelajar, 2007.

\section{JURNAL}

Anas, Muhammad Zarka, Dr., Leveraging Philanthropy : Monetary Waqf for Micro Finance, Paper presented to a symposium "Towards an Islamic
Micro Finance", Islamic Finance Project. Islamic Legal Studies Program. Harvard Law School. April 14,2007

Habib , Ahmed, , Waqf- Based Microfinance : Realizing The Social Role of Islamic Finance, Paper written for the International Seminar on "Integrating Waqf in The Islamic Financial Sector", Singapore. March 6- 7, 2007. Islamic Research and Training Institute (IRTI).

Juwaini Ahmed, dalam presentasi Arah Pengembangan Wakaf di Indonesia, yang disampaikan pada Seminar "Quo Vadis Wakaf di Indonesia", Tabung Wakaf Indonesia, Universitas Al- Azhar Indonesia. Jakarta, 28 Oktober 2009, mengutip hasil penelitian Universitas Islam Negeri (UIN) Syarif Hidayatullah Jakarta, menyampaikan bahwa $74 \%$ pengelola wakaf (nadzir) di Indonesia belum dapat memproduktifkan aset wakaf.

Magda Ismail Abdel Mohsin, The Institution of Waqf : A Non-Profit Institution to Financing the Needy Sectors, Paper presented to a conference "Research and Development: The Bridge between Ideals and Realities”, IIUM International 
Conference on Islamic Banking and

Finance. April 24, 2007.

Medias , Fahmi, Wakaf Produktif dalam

Perspektif Ekonomi Islam, Jurnal

Ekonomi Islam La_Riba, Volume

IV, No. 1, Juli 2010, hal.70

Muhammad, Kholid,. Raditya Sukmana dan Kamal Abdul Kareem Hassan, 2007, Waqf through Sukuk

Al Intifa'a : A Proposed Generic Model, Paper presented to a conference "Research and Development: The Bridge between Ideals and Realities". IIUM International Conference on Islamic Banking and Finance, April 24, 2007.

Mohsin, Ismail Abdel Magda, The Institution of Waqf : A Non-Profit Institution to Financing the Needy Sectors, Paper presented to a conference "Research and Development: The Bridge between Ideals and Realities", IIUM International Conference on Islamic Banking and Finance. April 24, 2007. Nasution, Mustafa Edwin E., M.Sc., MAEP., Ph.D., 2005, Wakaf uang dan Sektor Volunteer, Jakarta, Pusat Kajian Timur Tengah dan Islam Universitas Indonesia.
Rozalinda, Manajemen Risiko Investasi Wakaf Uang, Jurnal ISLAMICA, Vol. 6 No. 2, Maret 2012, hal. 301.

Setiawan Azis Abdul, Tantangan Strategis Institusi Wakaf dalam Program Pengentasan Kemiskinan Masyarakat, Jakarta, Jurnal Kordinat, Volume VIII No.1. 2007 Syafrudin Arif, Wakaf Tunai sebagai Alternatif Mekanisme Redistribusi Keuangan Islam, Jurnal Ekonomi Islam La_Riba, Volume IV, No. 1, Juli 2010

Yasir, Analisis Pembaruan Hukum Perwakafan, Jurnal Aplikasi Manajemen, Volume 7, Nomor 1, Februari 2009 